\title{
Solid-Phase Synthesis of Cyclic PNA and PNA-DNA Chimeras
}

\author{
Loredana Moggioa, Lorenzo De Napolib, Benedetto Di Blasioa Giovanni Di Fabiob ${ }^{b^{*}}$, Jennifer D'Onofriob, \\ Daniela Montesarchiob and Anna Messere ${ }^{a}$
}

a Dipartimento di Scienze Ambientali, Seconda Università di Napoli, Via Vivaldi, 43, 81100, Caserta, Italy

' Dipartimento di Chimica Organica e Biochimica, Università degli Studi di Napoli "Federico Il", Complesso Universitario di Monte S. Angelo, via Cynthia,4, 80126 Napoli - Italy.

\section{ELECTRONIC SUPPLEMENTARY INFORMATION:}

Experimental details 


\section{Table of contents}

General Methods $\quad$ S-3

Functionalization of Tentagel matrix and synthesis of support $3 \quad$ S-4

A typical procedure for the synthesis of cyclic $6(\mathbf{a}-\mathbf{b})$ and $8(a-c)$

$\begin{array}{lr}\text { HPLC profile of } 6 \mathrm{~b} & \text { S-7 }\end{array}$

HPLC profile of $\mathbf{8 b} \quad$ S-8

Maldi TOF spectrum of $6 \mathbf{a} \quad S-9$

$\begin{array}{ll}\text { Maldi TOF spectrum of } 6 \mathrm{~b} & \text { S-10 }\end{array}$

Maldi TOF spectrum of $\mathbf{8 a} \quad S-11$

Maldi TOF spectrum of $\mathbf{8 b} \quad S-12$

Maldi TOF spectrum of $8 \mathrm{c} \quad \mathrm{S}-13$

CD spectrum of $8 \mathbf{b} \quad S-14$

UV melting profile of $\mathbf{6} \mathbf{b}$ and $d\left({ }^{\prime} A G A G A G^{3}\right)$

UV melting profile of $\mathbf{8} \mathbf{b}$ and $d\left({ }^{\prime} A G A G A G^{3}\right)$ 


\section{General Methods}

${ }^{31} \mathrm{P}$ NMR spectra were recorded at $161.98 \mathrm{MHz}$ on a Bruker WM-400 spectrometer using $85 \% \mathrm{H}_{3} \mathrm{PO}_{4}$ as external standard.

MALDI TOF mass spectrometric analyses were performed on a PerSeptive Biosystems Voyager - De Pro MALDI mass spectrometer in the linear mode using a picolinic/3-hydroxypicolinic/sinapinic acid mixture as the matrix.

Purification of the crude material was carried out by gel filtration chromatography on a Sephadex G-10 column eluted with $\mathrm{H}_{2} \mathrm{O} / \mathrm{EtOH} 1: 1(\mathrm{v} / \mathrm{v})$. HPLC analyses were performed on Waters 600 Controller instrument equipped with a Waters 996 photodiode array detector and Millennium software. The desalted cyclic PNA $\mathbf{6 a}, \mathbf{6 b}$ and $\mathbf{8 c}$ were analyzed by HPLC on a RP- C18 Luna column (Phenomenex, $5 \mu \mathrm{m}, 150 \times 4.60 \mathrm{~mm}$ ) eluted with a linear gradient from 0 to $30 \%$ of $\mathrm{CH}_{3} \mathrm{CN}\left(0.1 \%\right.$ TFA, v/v) in $\mathrm{H}_{2} \mathrm{O}(0.1 \%$ TFA, v/v) in 40 min for $\mathbf{6} \mathbf{a}$ and $\mathbf{6} \mathbf{b}$, and with a linear gradient from 0 to $30 \%$ of $\mathrm{CH}_{3} \mathrm{CN}\left(0.1 \%\right.$ TFA, v/v) in $\mathrm{H}_{2} \mathrm{O}(0.1 \%$ TFA, v/v) in $90 \mathrm{~min}$ for $8 \mathrm{c}$, flow rate $1 \mathrm{~mL} / \mathrm{min}$, detection at $\lambda$ $=260 \mathrm{~nm}$. The desalted cyclic PNA-DNA chimeras $\mathbf{8 a}$ and $\mathbf{8 b}$ were analyzed by HPLC on Nucleogel SAX column (Macherey-Nagel, 1000-8/46) eluted with a linear gradient from 0 to $100 \% \mathrm{~B}$ in $\mathrm{A}$ in $15 \mathrm{~min}$. and 0 to $100 \%$ of $\mathrm{C}$ in $\mathrm{B}$ in $40 \mathrm{~min}$; flow rate $1 \mathrm{~mL} / \mathrm{min}$, detection at $\lambda=260 \mathrm{~nm}$. A: $\mathrm{H}_{2} \mathrm{O} ; \mathrm{B}: 20 \mathrm{mM} \mathrm{KH}_{2} \mathrm{PO}_{4}$ aq. solution, pH 7.0, containing 20 $\%(\mathrm{v} / \mathrm{v}) \mathrm{CH}_{3} \mathrm{CN}$; C: $1 \mathrm{M} \mathrm{KCl}, 20 \mathrm{mM} \mathrm{KH}_{2} \mathrm{PO}_{4}$ aq. solution, $\mathrm{pH} 7.0$, containing $20 \%(\mathrm{v} / \mathrm{v}) \mathrm{CH}_{3} \mathrm{CN}$.

Tentage ${ }^{\circledR}-\mathrm{NH}_{2}$ resin was purchased from Novabiochem. The functionalization of the solid support was carried out in a short glass column ( $5 \mathrm{~cm}$ length, $1 \mathrm{~cm}$ i.d.), equipped with a sintered glass filter, a stopcock and a cap.

The 3'-O-(2-cyanoethyl)-N,N-diisopropylphosphoramidite 2'-deoxyribonucleosides and Fmoc-PNA monomers as building blocks, the activator solution $\left(0.45 \mathrm{M}\right.$ tetrazole in $\left.\mathrm{CH}_{3} \mathrm{CN}\right)$ and the oxidizer solution $(0.02 \mathrm{M}$ iodine/THF/ $\mathrm{H}_{2} \mathrm{O} /$ pyridine) were all purchased from Applied Biosystems. The Fmoc-6-aminohexanoic acid (link k $_{3}$ was purchased from Sigma-Aldrich.

The spacer 2 (link1) was prepared according to Gaur R. K. et al. Nucleosides \& Nucleotides 1991, 10, 895.

The spacer DMTOCH${ }_{2}\left(\mathrm{CH}_{2}\right)_{4} \mathrm{COO}-\mathrm{Et}_{3} \mathrm{NH}^{+}$(link2) was prepared according to D'Onofrio, J. et al. Biooconj. Chem. $2005,16,1299$.

The ODN and PNA tracts were assembled on a PerSeptive Biosystems Expedite 8909 synthesizer, using commercially available 3'-O-(2-cyanoethyl)-N,N-diisopropylphosphoramidite 2'-deoxyribonucleosides and Fmoc-PNA monomers as building blocks respectively (scale $1 \mu \mathrm{mol}$ for DNA synthesis and $2 \mu \mathrm{mol}$ for PNA synthesis).

Conventional abbreviations are used. 


\section{Functionalization of the Tentagel matrix and synthesis of 3}

$500 \mathrm{mg}$ of TentaGe ${ }^{\circledR}-\mathrm{NH}_{2} \mathrm{LL}(0.29 \mathrm{meg} / \mathrm{g}, 0.15 \mathrm{mmol})$ were reacted, at it overnight, with a mixture of $280 \mathrm{mg}$ (1.5 $\mathrm{mmol})$ of 3-chloro-4-hydroxy-phenylacetic acid, $310 \mathrm{mg}(1.5 \mathrm{mmol})$ of DCC, $255 \mu \mathrm{L}$ of N,N-diisopropylethylamine (DIPEA) and $227 \mathrm{mg}(1.5 \mathrm{mmol})$ of $\mathrm{N}$-hydroxybenzotriazole $\left(\mathrm{HOBt} \cdot \mathrm{H}_{2} \mathrm{O}\right)$ dissolved in $6 \mathrm{~mL}$ of anhydrous pyridine. After exhaustive washings with dichlorometane (DCM), $\mathrm{CH}_{3} \mathrm{OH}$ and $\mathrm{Et}_{2} \mathrm{O}$, the support was dried under reduced pressure. By Kaiser test, the incorporation of the linker was almost quantitative. After capping of the unreacted amino functions with $\mathrm{Ac}_{2} \mathrm{O} / \mathrm{Py}(1: 1, \mathrm{v} / \mathrm{v})$ for $1 \mathrm{~h}$ at rt, the support was treated with conc. aq. ammonia $(28 \%)$ at $50{ }^{\circ} \mathrm{C}$ for $1 \mathrm{~h}$. After exhaustive washings with $\mathrm{CH}_{3} \mathrm{OH}, \mathrm{DCM}$ and $\mathrm{Et}_{2} \mathrm{O}$, resulting support 1 was dried under reduced pressure.

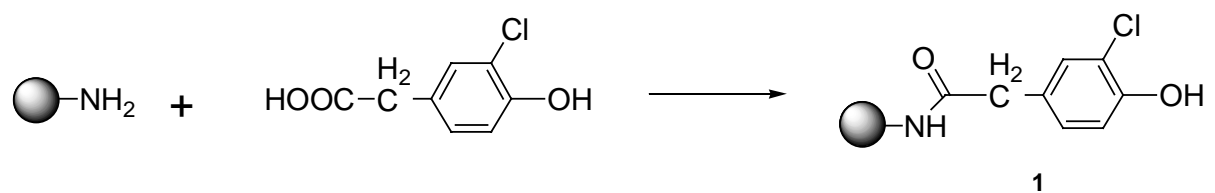

$4.9 \mathrm{~mL}$ (2.2 mmol) of a commonly used 'activator solution' ( $0.45 \mathrm{M}$ tetrazole in $\mathrm{CH}_{3} \mathrm{CN}$ ) were added to $183 \mathrm{mg}$ $(0.35 \mathrm{mmol})$ of the 6-N-(4-methoxytriphenylmethyl)-aminohexyl-1-O-(2-cyanoethyl)-N,Ndiisopropylphosphoramidite 2 and $500 \mathrm{mg}(0.29 \mathrm{meg} / \mathrm{g}, 0.14 \mathrm{mmol})$ of support 1 . After $1 \mathrm{~h}$ the support was exhaustively washed with $\mathrm{CH}_{3} \mathrm{CN}$ and treated (3 times) with $5 \mathrm{~mL}$ of a commonly used 'oxidizer' solution ( $\mathrm{l}_{2} /$ pyridine/ $\mathrm{H}_{2} \mathrm{O} / \mathrm{THF}$ ) for 5 min. After exhaustive washings with $\mathrm{CH}_{3} \mathrm{CN}, \mathrm{DCM}$ and $\mathrm{Et}_{2} \mathrm{O}$, the resulting support was dried under reduced pressure. The complete oxidation of the phosphite triester to phosphate triester, leading to support 3, was monitored by ${ }^{31} \mathrm{P}$ NMR of the resin suspended in $\mathrm{CDCl}_{3}$. Typically, a relevant upfield shift of the signal at $135 \mathrm{ppm}$ to two signals centered at ca. $-6.7 \mathrm{ppm}$ was observed. Incorporation yields of the aminohexanol linker were always in the range $55-70 \%(0.16-0.20 \mathrm{meq} / \mathrm{g})$, as determined by quantitative monomethoxytriphenylmethyl (MMT) cation test performed on dried and weighed samples of support 3.

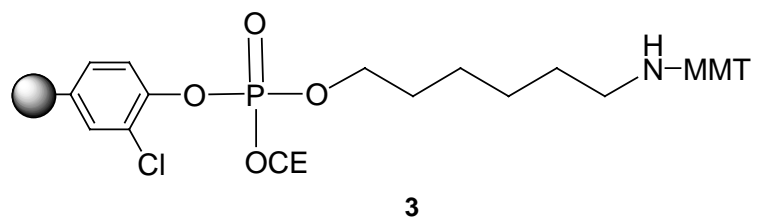




\section{A typical procedure for the synthesis of cyclic $6 a$ and $6 \mathrm{~b}$ (Scheme 2)}

Starting from $50 \mathrm{mg}$ of support $3(0.18 \mathrm{meq} / \mathrm{g}, 9.0 \mu \mathrm{mol})$, the PNA tracts were assembled on a PerSeptive Biosystems Expedite 8909 synthesizer, using commercially available Fmoc-PNA monomers as building blocks (scale $2 \mu \mathrm{mol})$.

The steps concerning, respectively, Fmoc removal, coupling, and capping of the unreacted amino groups were carried using: (i) 20\% piperidine in DMF; (ii) $0.22 \mathrm{M} \mathrm{Fmoc-PNA} \mathrm{addition} \mathrm{monomer} \mathrm{in} \mathrm{DMF} \mathrm{and} 0.18 \mathrm{M}$ HATU in DMF; (iii) $5 \%$ acetic anhydride, $6 \%$ lutidine in DMF.

The resulting supports $\mathbf{4}(\mathbf{a}-\mathbf{b})$ were first dried under reduced pressure and then reacted with a mixture of DCC $(0.9$

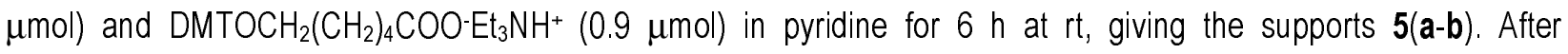
detritylation with a $1 \%$ DCA solution in DCM, the resulting supports were dried under reduced pressure and then reacted with 1-mesitylenesulfonyl-3-nitro-1,2,4-triazole (MSNT, $0.1 \mathrm{M}$ in pyridine) at it for $18 \mathrm{~h}$.

After cleavage and deprotection $\left(0.1 \mathrm{M} \mathrm{NaOH}\right.$ in $\mathrm{H}_{2} \mathrm{O} /$ dioxane, $1: 1, \mathrm{v} / \mathrm{v}, 50^{\circ} \mathrm{C}$, overnight), the crude detached material was then redissolved in $\mathrm{H}_{2} \mathrm{O} / \mathrm{EtOH}(1: 1, \mathrm{v} / \mathrm{v})$ and purified by gel filtration chromatography on a Sephadex $\mathrm{G}$ 10 column. The isolated compounds were checked for purity by analytical HPLC and identified on the basis of their MALDI-TOF spectra.

\section{A typical procedure for the synthesis of cyclic $8 \mathrm{a}$ and $\mathbf{8 b}$ (Scheme 2)}

Starting from $50 \mathrm{mg}$ of support $\mathbf{5}(\mathbf{a}-\mathbf{b})(0.12 \mathrm{meq} / \mathrm{g}, 6.0 \mu \mathrm{mol})$, the ODN tracts were assembled on a PerSeptive Biosystems Expedite 8909 synthesizer, using commercially available 3'-O-(2-cyanoethyl)-N,Ndiisopropylphosphoramidite 2'-deoxyribonucleosides as building blocks (scale $1 \mu \mathrm{mol}$ ).

The DMT removal, coupling, capping and oxidation steps were carried out using respectively: (i) 1\% DCA in DCM; (ii) 0.2 M 3'-O-(2-cyanoethyl)-N,N-diisopropylphosphoramidite 2'-deoxyribonucleoside monomers in $\mathrm{CH}_{3} \mathrm{CN}$ and 0.5 $M$ tetrazole in $\mathrm{CH}_{3} \mathrm{CN}$; (iii) THF/lutidine $/ \mathrm{Ac}_{2} \mathrm{O}$ (8:1:1); (iv) $0.05 \mathrm{M} \mathrm{I}_{2}$ in $\mathrm{THF} / \mathrm{H}_{2} \mathrm{O} /$ pyridine (7:2:1).

After detritylation of $\mathbf{7}(\mathbf{a}-\mathbf{b})$ with a $1 \%$ DCA solution in DCM, the resulting supports were dried under reduced pressure and then reacted with 1-mesitylenesulfonyl-3-nitro-1,2,4-triazole (MSNT, $0.1 \mathrm{M}$ in pyridine) at rt for $18 \mathrm{~h}$.

After cleavage and deprotection $\left(0.1 \mathrm{M} \mathrm{NaOH}\right.$ in $\mathrm{H}_{2} \mathrm{O} /$ dioxane, $1: 1, \mathrm{v} / \mathrm{v}, 50{ }^{\circ} \mathrm{C}$, overnight), the crude detached material was then redissolved in $\mathrm{H}_{2} \mathrm{O} / \mathrm{EtOH}(1: 1, \mathrm{v} / \mathrm{v})$ and purified by gel filtration chromatography on a Sephadex G10 column. The isolated compounds were checked for purity by analytical HPLC and identified on the basis of their MALDI-TOF spectra. 


\section{A general procedure for the synthesis of cyclic $8 \mathrm{c}$ (Scheme 2)}

Starting from $50 \mathrm{mg}$ of support $3(0.18 \mathrm{meq} / \mathrm{g}, 9.0 \mu \mathrm{mol})$, the PNA tracts were assembled on a PerSeptive Biosystems Expedite 8909 synthesizer, using commercially available Fmoc-PNA monomers as building blocks (scale $2 \mu \mathrm{mol})$.

The steps concerning, respectively, Fmoc removal, coupling, and capping of the unreacted amino groups were carried out using: (i) 20\% piperidine in DMF; (ii) $0.22 \mathrm{M} \mathrm{Fmoc-PNA} \mathrm{addition} \mathrm{monomer} \mathrm{in} \mathrm{DMF} \mathrm{and} 0.18 \mathrm{M}$ HATU in DMF; (iii) $5 \%$ acetic anhydride, $6 \%$ lutidine in DMF.

The resulting support $\mathbf{4 c}$ was first dried under reduced pressure and then reacted with a mixture of DCC $(0.9$ $\mu \mathrm{mol})$ and 6-Fmoc-aminohexanoic acid $(0.9 \mu \mathrm{mol})$ in pyridine for $6 \mathrm{~h}$ at rit, giving support $6 \mathbf{c}$. After Fmoc removal with a $20 \%$ piperidine solution in DMF, the resulting support was dried under reduced pressure. Next, the second PNA tract was assembled following the same procedure above described for the synthesis of $\mathbf{6 a}$ and $\mathbf{6} \mathbf{b}$. 
is. 7 Telefono 02/57.40.96 90 Telefax 02/57.40.95.88

\section{AUfs: 2}

HPLC profile of $6 \mathbf{a}$<smiles></smiles>

๑罗

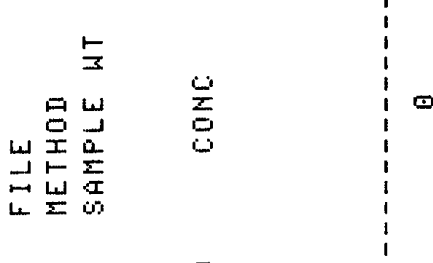

呈

$\stackrel{x}{2}>$

$x \quad 9 \overrightarrow{0} 12$

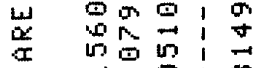
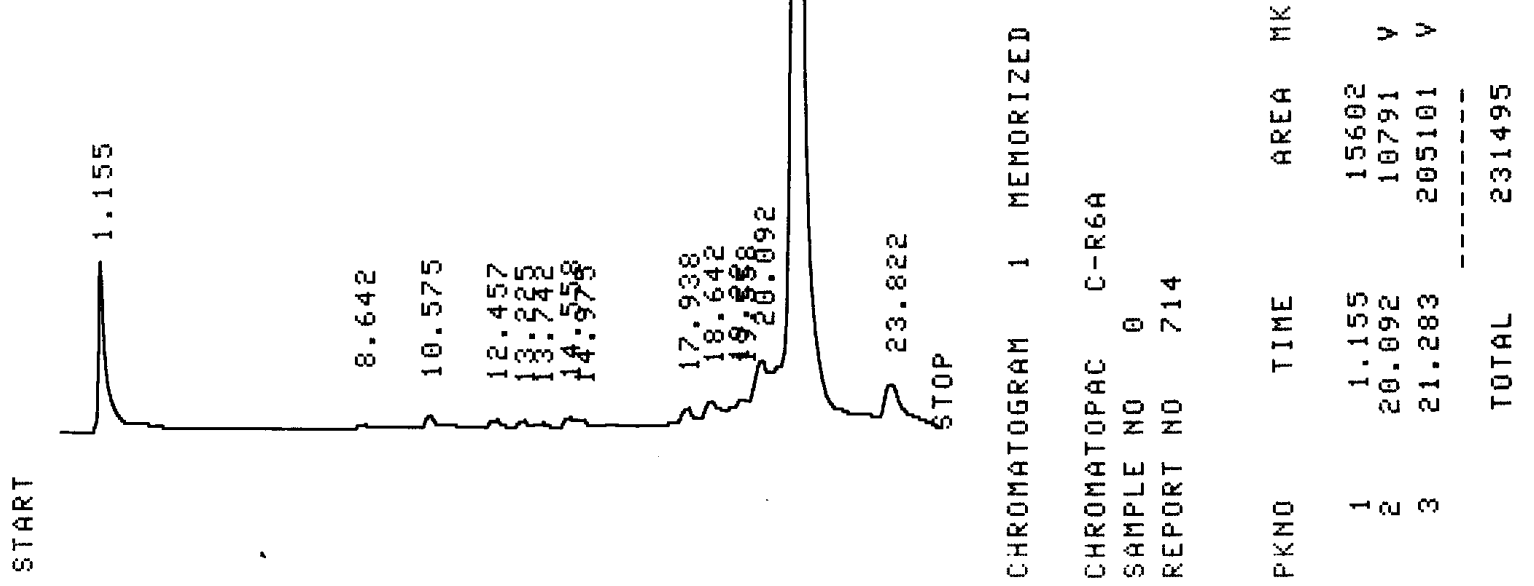


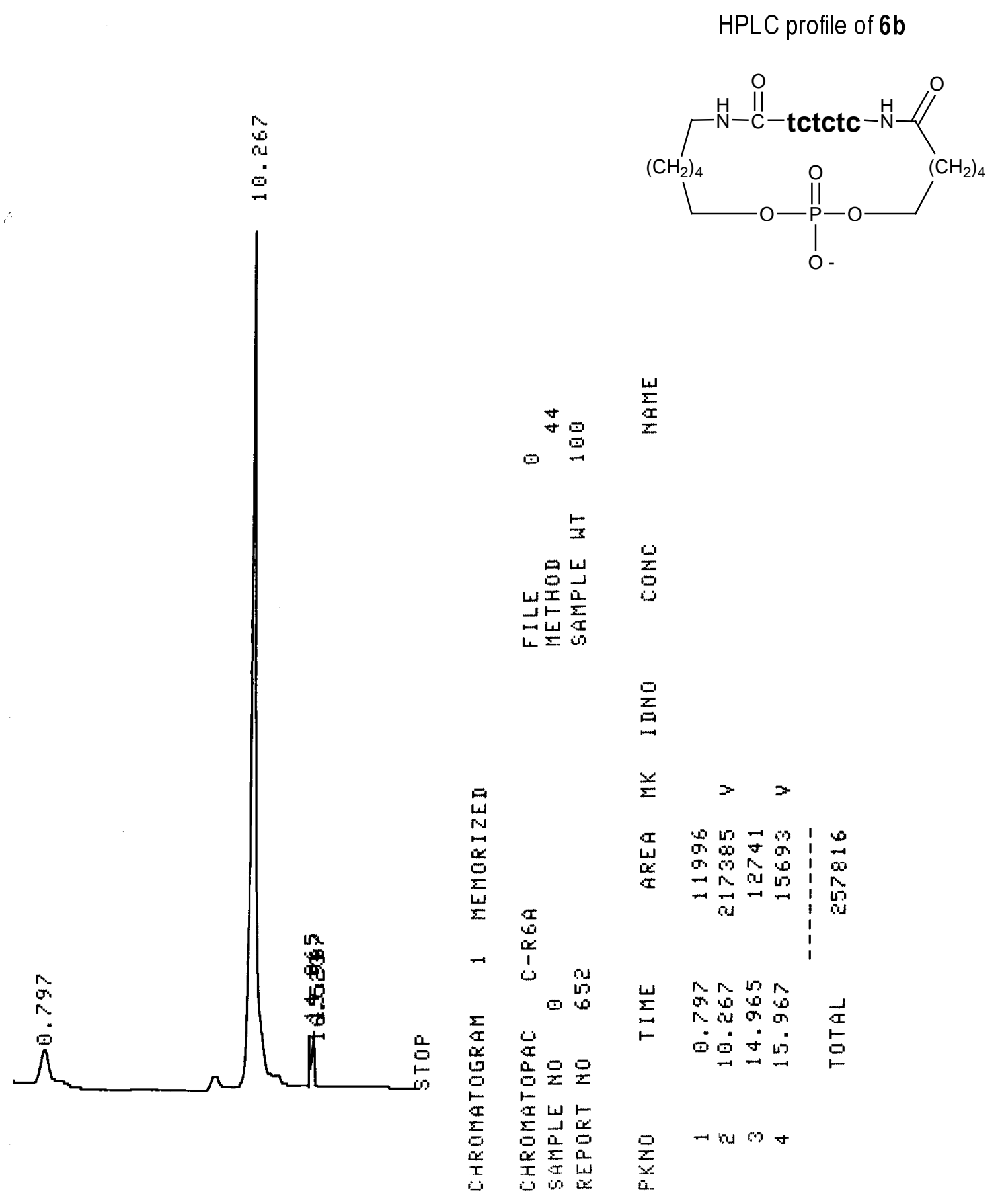




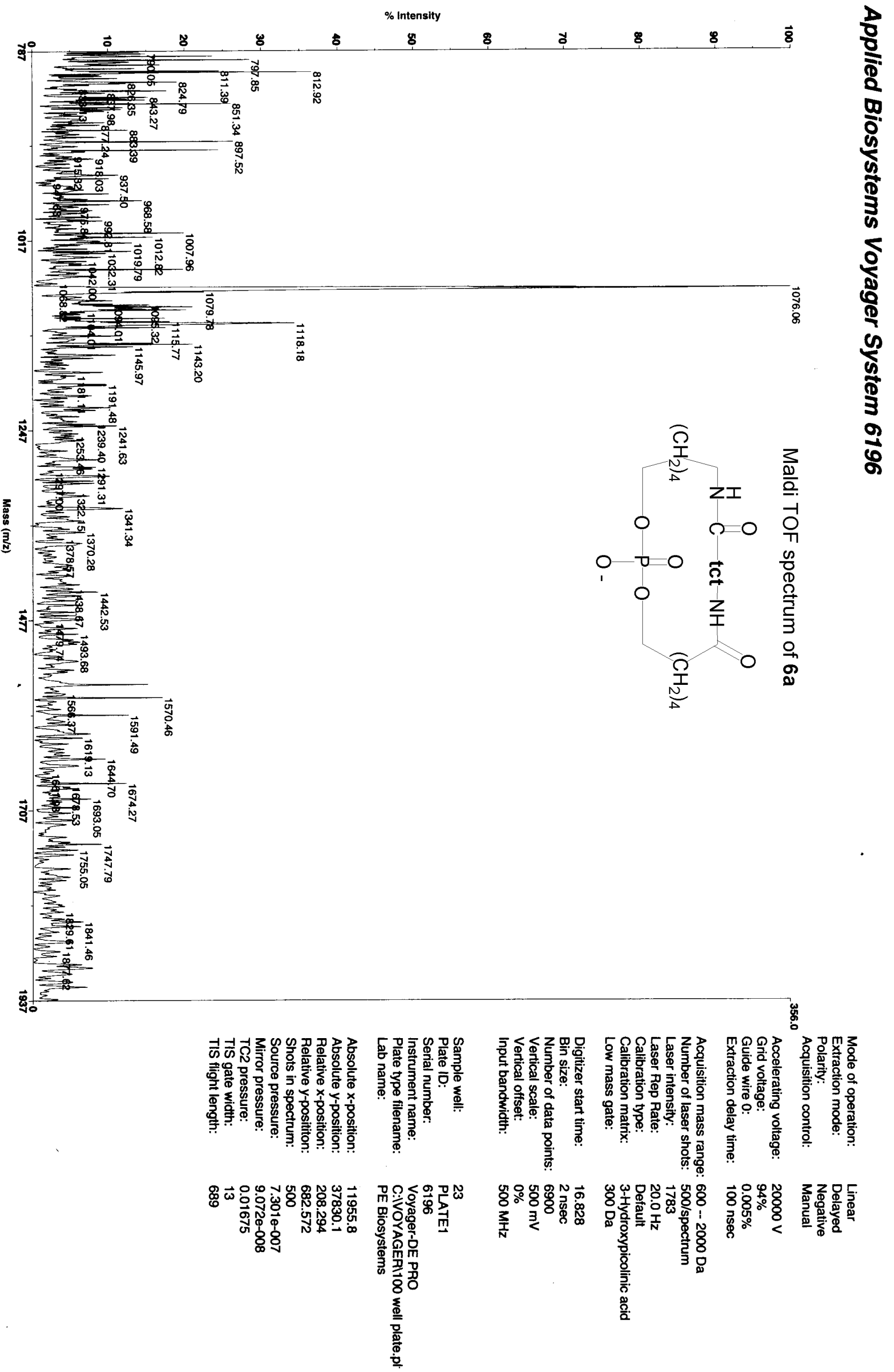




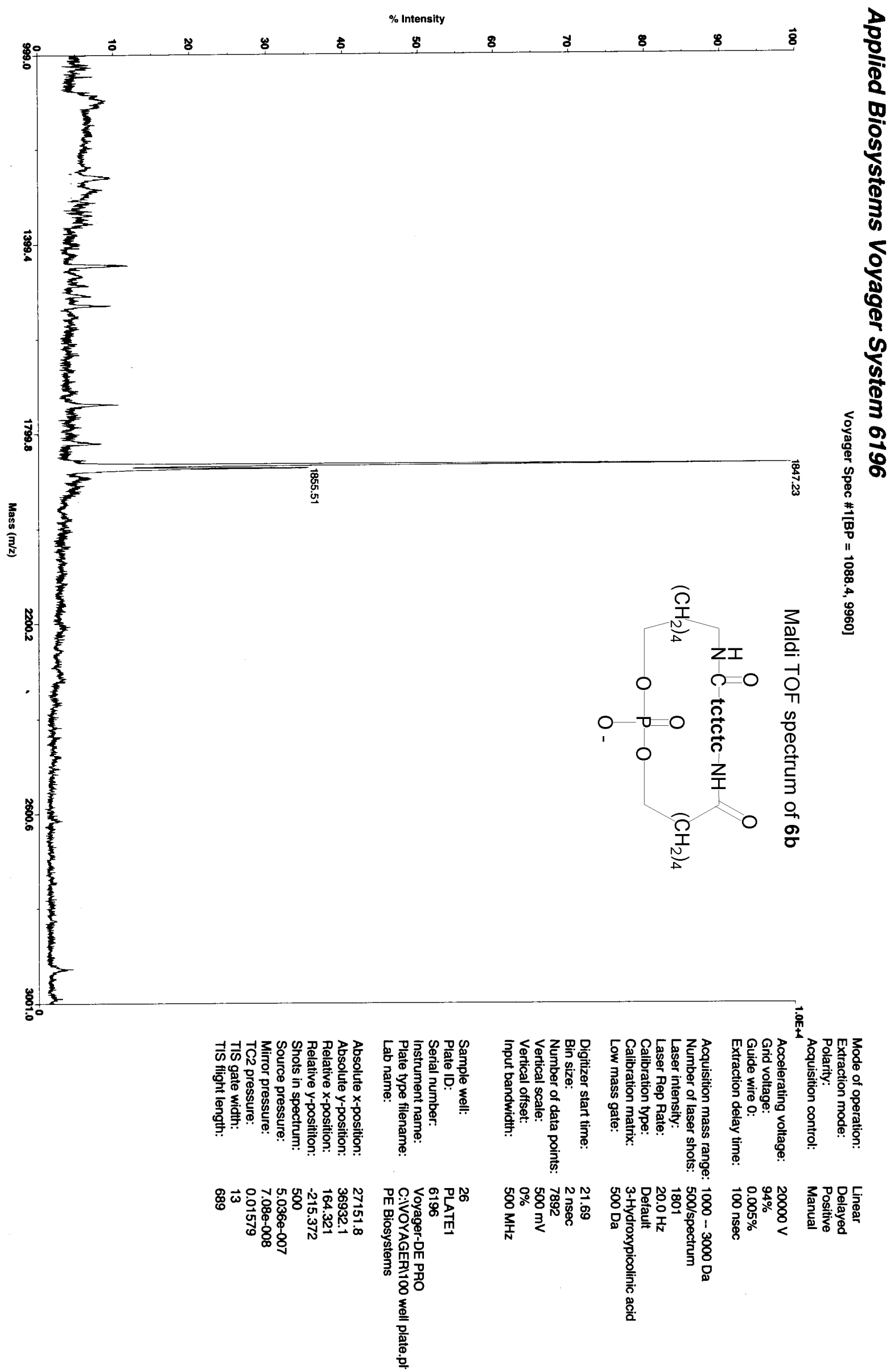




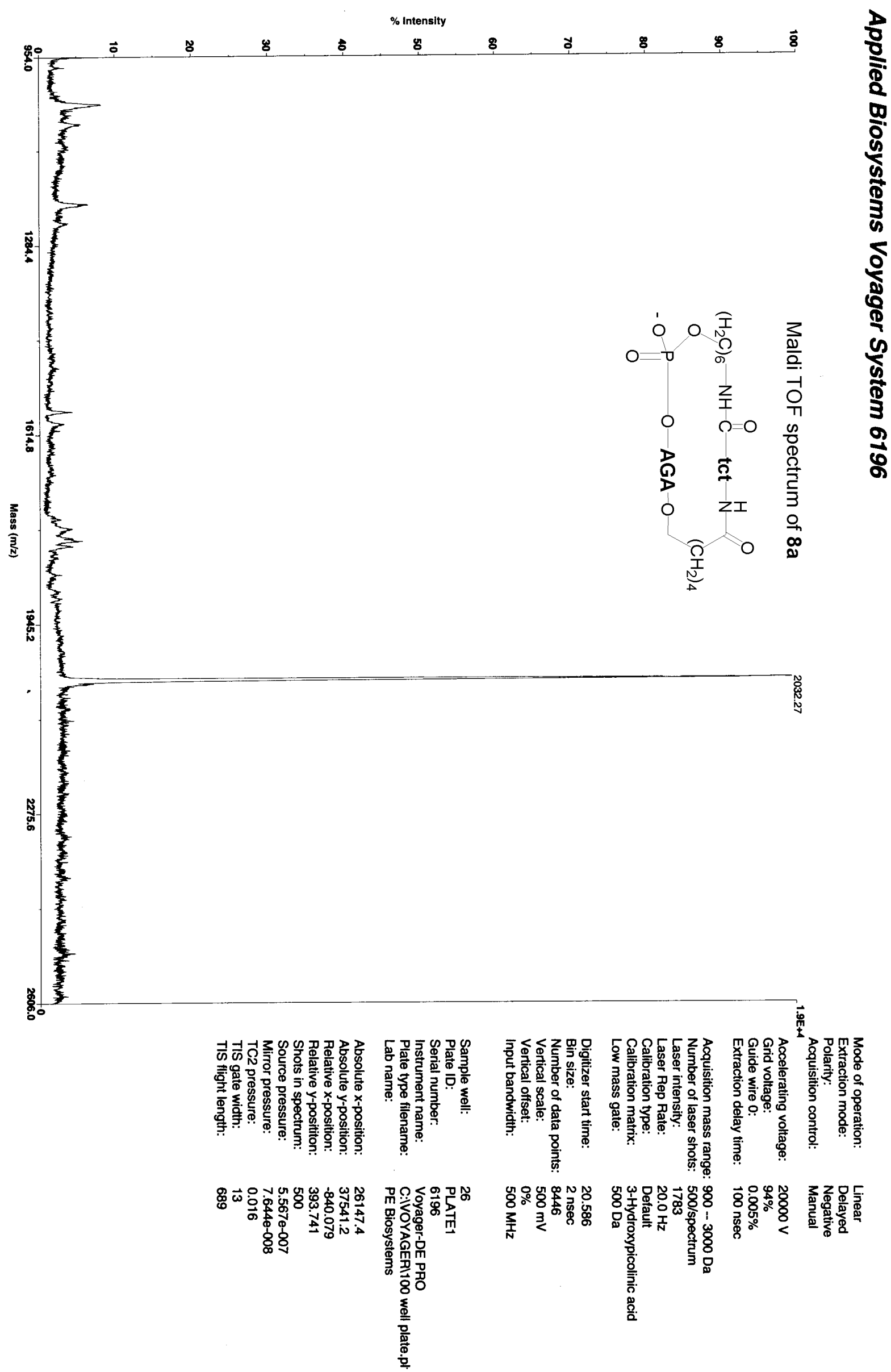




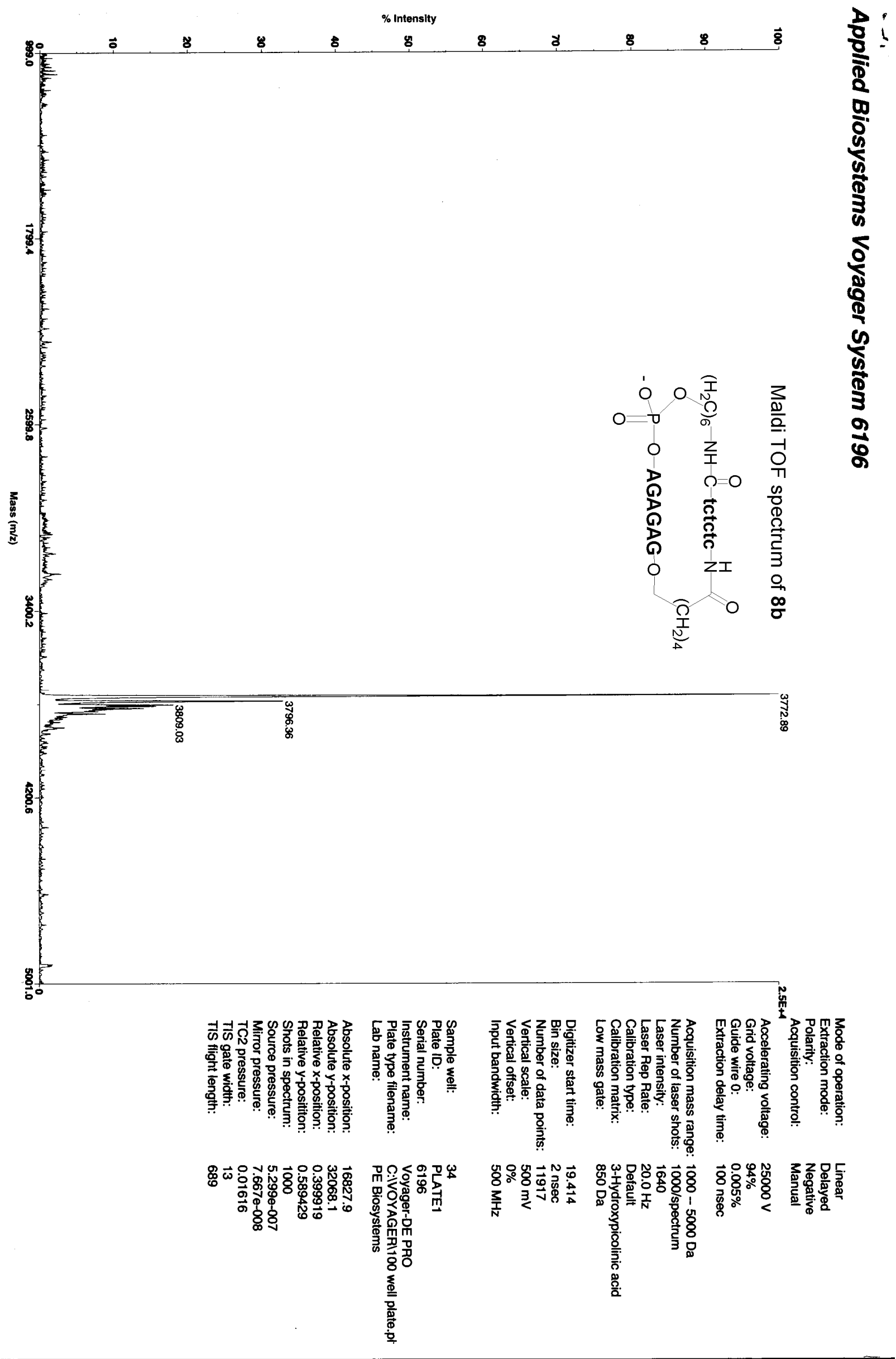




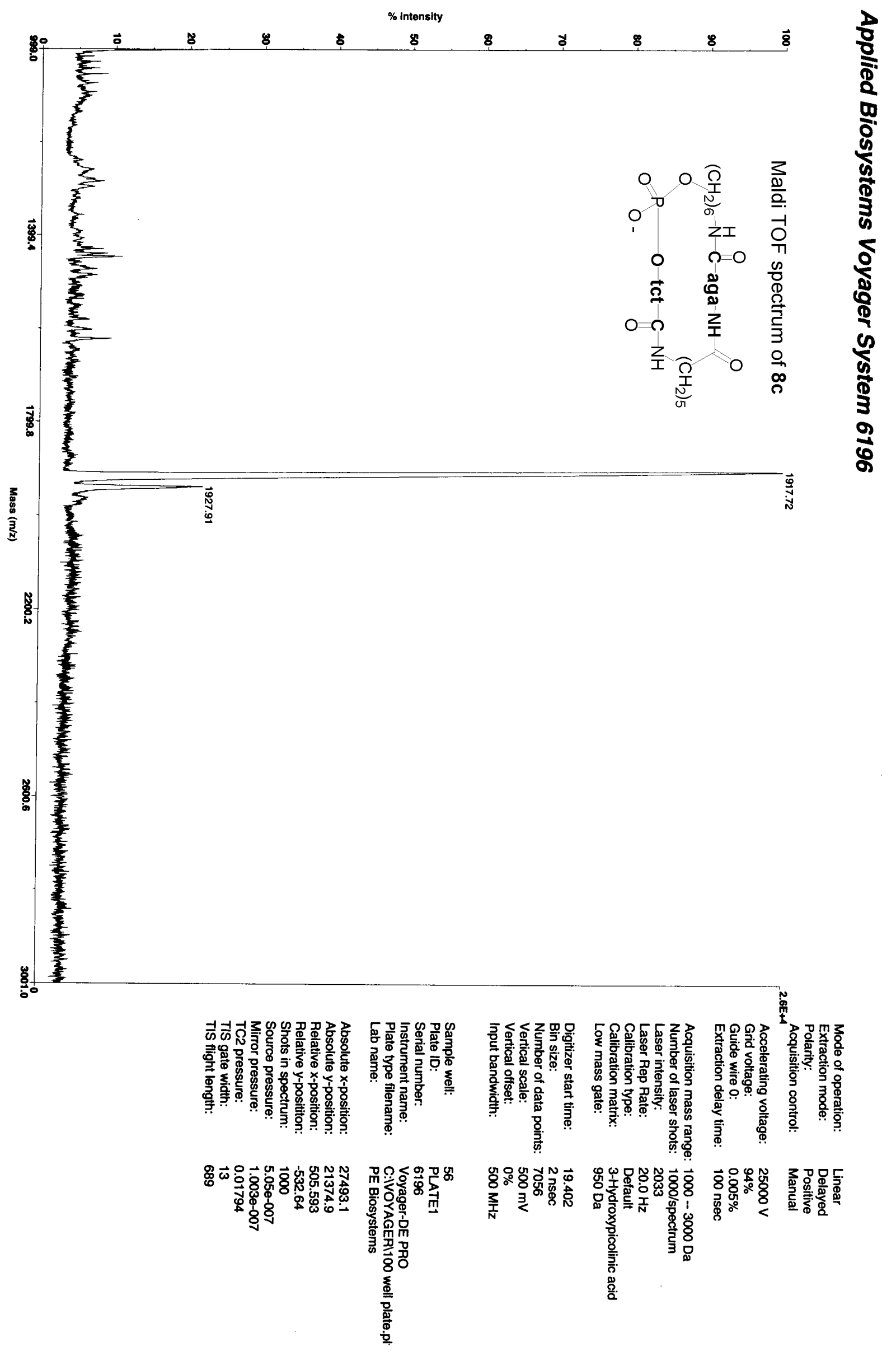




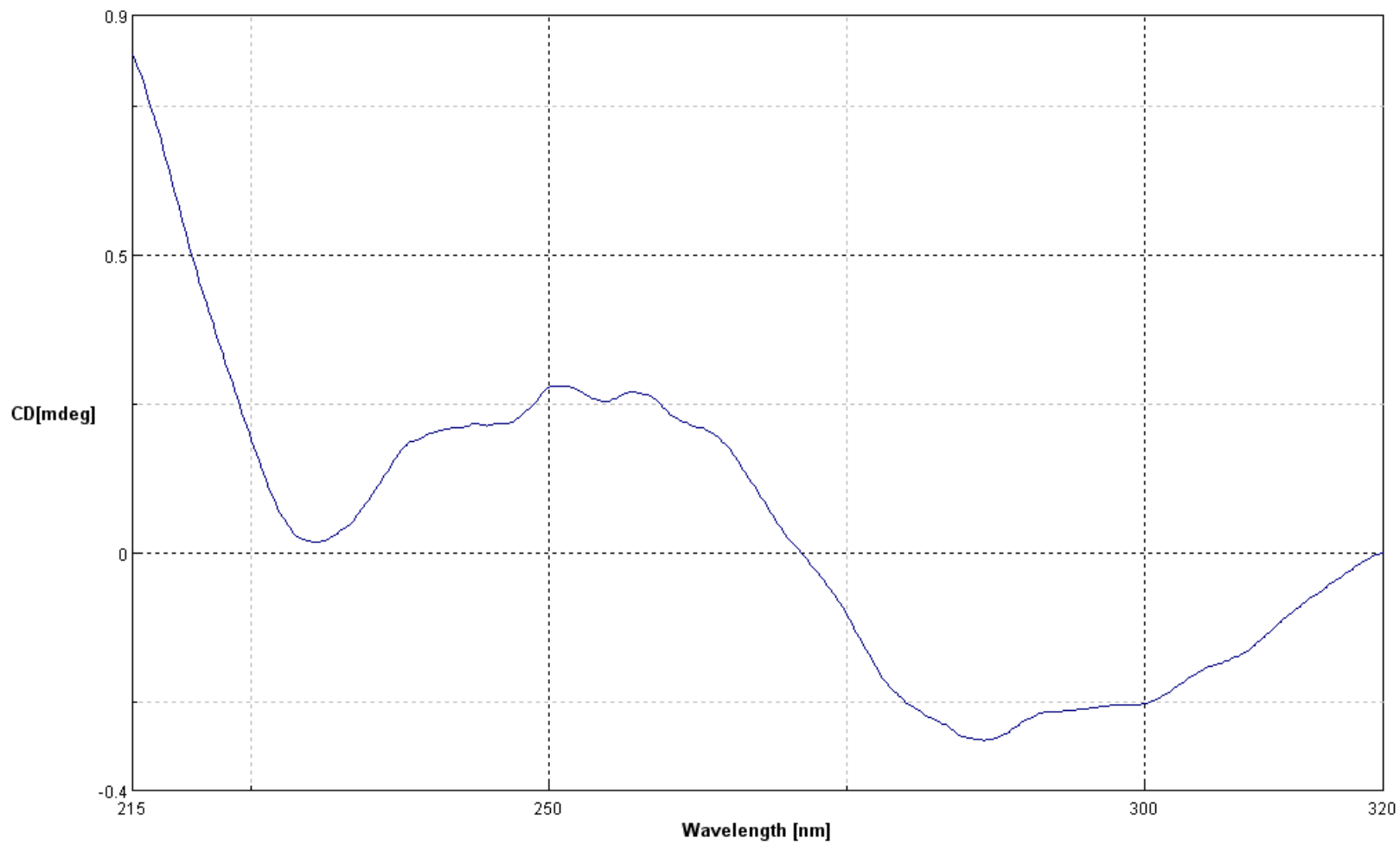

CD spectrum of cyclic chimera $8 \mathbf{b}\left(100 \mathrm{mM} \mathrm{NaCl}_{1} 10 \mathrm{mM} \mathrm{K}_{2} \mathrm{HPO}_{4}, \mathrm{pH}=7.0\right) 1.5 \mu \mathrm{M}$, at $25^{\circ} \mathrm{C}$.

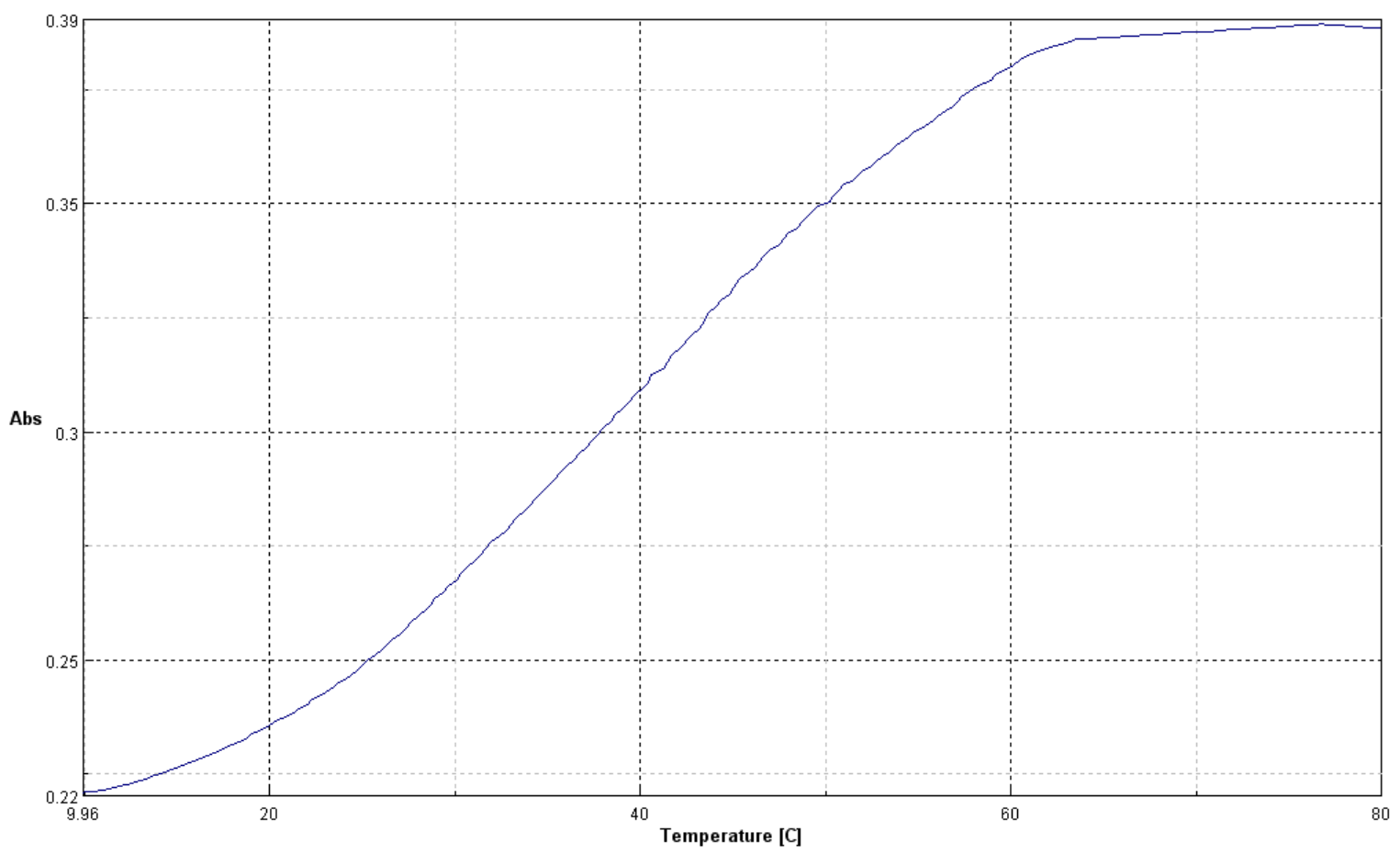

UV-melting profile of $6 \mathbf{b}$ and $d\left({ }^{\prime} \mathrm{AGAGAG}^{\prime}\right)$, dissolved in $100 \mathrm{mM} \mathrm{NaCl}, 10 \mathrm{mM} \mathrm{K}_{2} \mathrm{HPO}_{4}, \mathrm{pH}=7.0,3.5 \mu \mathrm{M}$ each strand, registered at $260 \mathrm{~nm}\left(0.5^{\circ} \mathrm{C} / \mathrm{min}\right) ; \mathrm{Tm}=49.0^{\circ} \mathrm{C}$. 


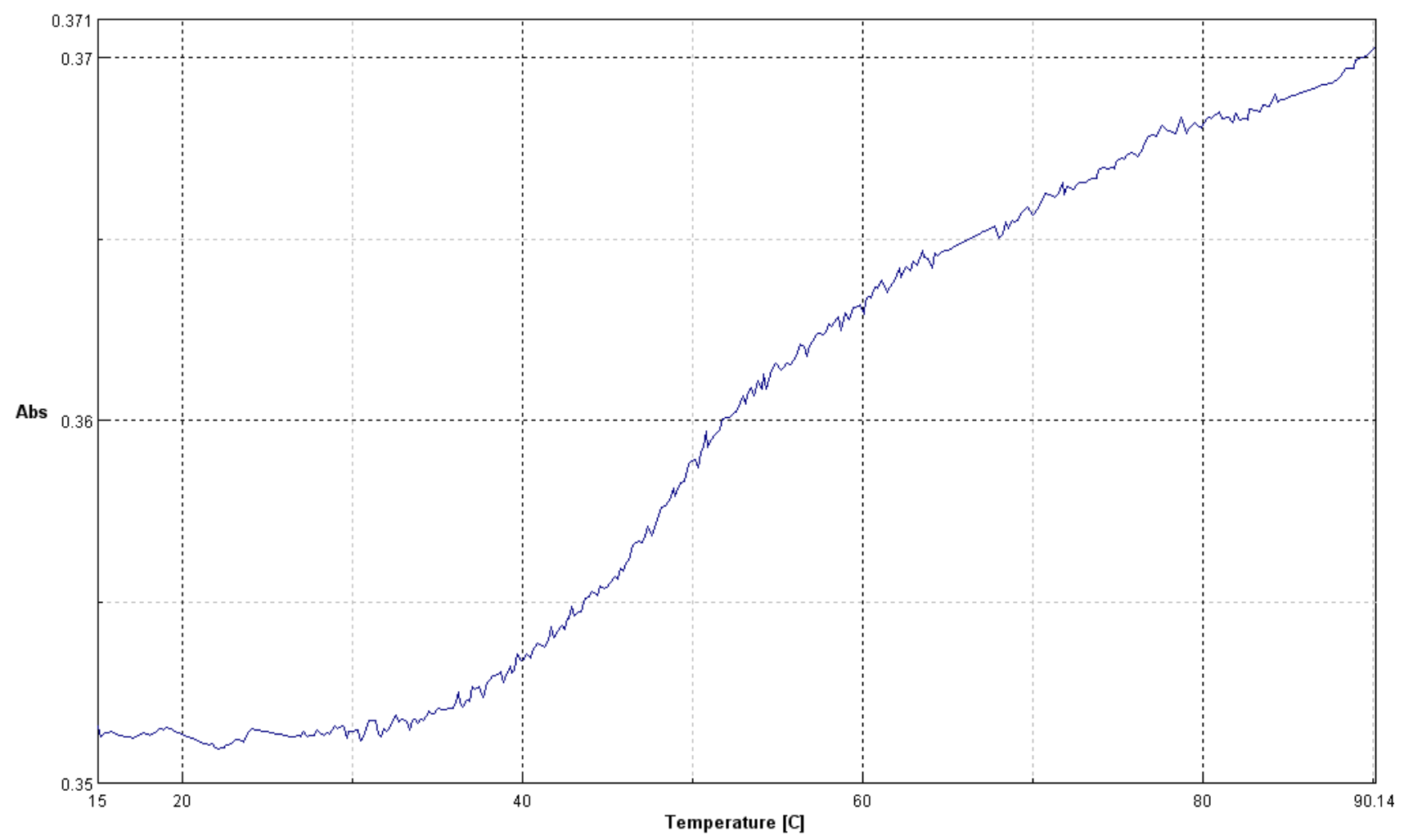

UV-melting profile of $8 \mathbf{b}$ and $d\left({ }^{\prime} \mathrm{AGAGAG}^{3}\right)$, dissolved in $100 \mathrm{mM} \mathrm{NaCl}, 10 \mathrm{mM} \mathrm{K}_{2} \mathrm{HPO}_{4}, \mathrm{pH}=7.0,3.5 \mu \mathrm{M}$ each strand, registered at $260 \mathrm{~nm}\left(0.5^{\circ} \mathrm{C} / \mathrm{min}\right) ; \mathrm{Tm}=52.0^{\circ} \mathrm{C}$. 